\title{
Floristic Composition, Vegetation Structure, and Regeneration Status of Woody Plant Species of Oda Forest of Humbo Carbon Project, Wolaita, Ethiopia
}

\author{
Markos Kuma ${ }^{1}$ and Simon Shibru ${ }^{2}$ \\ ${ }^{1}$ Department of Biology, Wolaita Sodo University, P.O. Box 138, Wolaita Sodo, Ethiopia \\ ${ }^{2}$ Department of Biology, Arba Minch University, P.O. Box 21, Arba Minch, Ethiopia
}

Correspondence should be addressed to Markos Kuma; kuma.markos03@gmail.com

Received 29 June 2015; Accepted 3 September 2015

Academic Editor: Zed Rengel

Copyright (C) 2015 M. Kuma and S. Shibru. This is an open access article distributed under the Creative Commons Attribution License, which permits unrestricted use, distribution, and reproduction in any medium, provided the original work is properly cited.

\begin{abstract}
Our current study was conducted in Oda forest to explore floristic composition, vegetation structure, and regeneration of woody species in a newly established Humbo Carbon Project. In the project, the above information for sufficient conservation and management of the forest is not well documented. Data were collected in October and December 2014. Thirty-two quadrats $(20 \mathrm{~m} \times$ $20 \mathrm{~m}$ ) lying $100 \mathrm{~m}$ far apart were used for shrub and tree data. In each major plot, subplots $\left(1 \mathrm{~m}^{2}\right)$ were established at the center and corner for seedlings and saplings data. Altitude, slope, and aspect were measured using GPS and clinometers. DBH, basal area, and IVI were used for vegetation structure. Among 62 species confined in 32 families and 54 genera, Dodonaea angustifolia and Combretum molle were the densest and the most dominant and frequent species with higher IVI. Altitude and slope had significant effect $(p<0.0001)$ on basal area and dominance. Bell and inverted J shaped patterns of selected woody species were identified. The seedling, sapling, and matured tree had $2.3 \%, 23.7 \%$, and $74 \%$ density ha ${ }^{-1}$ of individuals, respectively. Generally, the study confirmed that very few species had dominance and abundance, influence of altitude and slope on species distribution, and fair regeneration of the forest.
\end{abstract}

\section{Introduction}

Diverse physiographic, altitudinal, climatic, and edaphic difference enables Ethiopia to have various types of vegetation ranging from alpine to desert plant communities [1] which provide economical, sociocultural, and environmental benefits. Many studies confirmed that forests have an important role in maintaining the productivity of the environment; trees provide food for animals, serve as a standing cover to protect the land from wind and water erosion, stabilizing the water cycle, facilitate the process of evaporation, and keep the soil porous; they are also used for construction as well as for tools, furniture, fuel, medicine, grass, and herbage and for forage and provide edible fruits. They serve to absorb carbon dioxide to reduce global warming, give off oxygen, and renew the atmosphere. Plants also serve as a source of income by attracting tourists, serve as recreational facilities, prevent lakes and dams from silting, and clean, regulate, and distribute water resources [1-6]. Hence, forests sequester and store more carbon than any terrestrial ecosystem; that is, they store more than $80 \%$ of all terrestrial above ground carbon and more than $70 \%$ of all soil organic carbon $[7,8]$. To do so stable climate is crucial but the climate of Ethiopia has been changing due to global and local effects of vegetation degradation $[4,9]$. In Ethiopia different factors like deforestation, overharvesting, and permanent conversion to other forms of land use are leading to shrinkage of forest resources. In addition to anthropogenic activities, forest can be affected by different environmental factors such as altitude, slope, and aspect by affecting the patterns of tree species distribution $[10,11]$.

The forests of Humbo Woreda have been cleared only within the last thirty to fifty years as the demand for energy, construction wood, food, fodder, and feed has increased as a result of the increase both in human and in livestock 
population [12]. The main causes of deforestation and forest degradation at Humbo are tree cutting for wood fuel and construction materials production for sale especially to compensate food shortage created by erratic and scarce rainfall in the area over a long period of time. Oda forest was one of the forests of Humbo Woreda victimized by these anthropogenic activities as well as environmental factors. Awareness and knowledge on sustainable use and management were very much less even though the Humbo Carbon Project forests like Oda forest provide ecological services and socioeconomic values to local communities. Therefore, Humbo CommunityBased Forest Management Project was established with the aim of sequestering $\mathrm{CO}_{2}$ through regeneration of native forest utilizing the farmer managed natural regeneration technique [13].

The Humbo Community-Based Natural Regeneration Project forests act as a carbon "sink" to mitigate climate change while at the same time building environmental, social, and economic resilience for future climate change impacts. Over 90 percent of the Humbo project area is being reforested from the stumps of previously cut down (but still living) trees. To date, 2,728 hectares of degraded forest that was being continually exploited for wood, charcoal, and fodder extraction has been protected and is now being restored and sustainably managed [14]. Of that, 340.04 hectares is covered by Oda forest.

The diversity, regeneration status, floristic composition, and vegetation structure are crucial elements to clearly visualize the anthropogenic activities as well as environmental factors affecting the vegetation of an area. Hence, for forest management accurate data on forest resources is considered to be an essential requirement [15], but as a result of being a newly established Carbon Project such a kind of information is not well documented in Oda forest. The lack of such basic information is one of the serious problems that hamper sufficient conservation and management of the forest. Therefore, this study intended to solve such a basic problem hindering observation of the next phenomenon.

\section{Materials and Methods}

2.1. Description of the Study Area. This study was carried out in Oda forest which is $25 \mathrm{~km}$ away from Humbo Tebela, the town of the Humbo district, which is located $420 \mathrm{~km}$ away from Addis Ababa. The forest is found in SNNPR, Wolaita zone, Humbo Woreda, Hobicha Bongota kebele $\left(6^{\circ} 44^{\prime}\right.$ and $37^{\circ} 52^{\prime} \mathrm{N} ; 37^{\circ} 53^{\prime}$ and $\left.38^{\circ} 00^{\prime} \mathrm{E}\right)$, Figure 1 . It lies within the midland relatively low agroecological zone at altitude ranges from 1625 to 1929 masl and the vegetation can be classified as the dry woodland forest type. It had been covered by dense vegetation of broad-leaved vegetation types and montane forests before they were cleared around fifty years ago [12].

2.2. Data Collection. The data collection was conducted from October to December 2014. A total of 32 quadrats $(20 \mathrm{~m} \times$ $20 \mathrm{~m}$ ) lying far apart at $100 \mathrm{~m}$ were used for shrub and tree data based on aspect of the vegetation. In each major plot, subplots $\left(1 \mathrm{~m}^{2}\right)$ were established at the center and corner for seedlings and saplings data. All woody species with
$\mathrm{DBH} \geq 2.5 \mathrm{~cm}$ were recorded and their growth habits described. Individuals having $\mathrm{DBH}<2.5 \mathrm{~cm}$ and height $\leq 0.6 \mathrm{~m}$ were counted as seedling whereas individuals with $2.5 \mathrm{~cm} \leq \mathrm{DBH} \leq 15 \mathrm{~cm}$ and $0.61 \leq$ height $\leq 3 \mathrm{~m}$ were counted as sapling. The $\mathrm{DBH}$ was measured at $1.3 \mathrm{~m}$ from the ground. Altitude, slope, and aspect were measured using GPS and clinometers. Species not identified on spot were identified using published volumes of the Flora of Ethiopia and Eritrea and ETH [16-20].

2.3. Data Analysis. Density, Diameter at Breast Height $(\mathrm{DBH})$, frequency, dominance, basal area, and IVI were used for description of vegetation structure. Bar graphs were developed using the DBH versus density of individuals for four arbitrary diameter classes $(1 \leq 5 \mathrm{~cm}, 2=5.1-10 \mathrm{~cm}, 3=10.1-$ $15 \mathrm{~cm}$, and $4 \geq 15 \mathrm{~cm}$ ) of the forest as well as the selected dominant species. The structural parameters were analyzed using the following formula:

(1) Basal area of a tree $=C^{2} / 4 \pi$ or $\pi\left(C^{2} / 39.5\right)$.

(2) Diameter at Breast Height $(\mathrm{DBH})=(C / \pi)$.

(3) Dominance $=$ total cover or basal area of species A/ area sampled.

(4) Relative dominance $=$ dominance for species A/total dominance of all species $\times 100$.

(5) Density $=$ (number of individuals of species A/area sampled).

(6) Relative density $=$ (number of individuals of species A/total number of individuals in area) $\times 100$.

(7) Frequency $=$ (number of plots in which species $\mathrm{A}$ occurs/total number of plots sampled).

(8) Relative frequency $=$ (frequency value for species A/ total of all frequency values for all species) $\times 100$.

(9) Importance value $=$ relative density + relative frequency + relative dominance.

Regeneration status of the forest was analyzed by comparing saplings and seedlings with the matured trees according to Dhaulkhandi et al. [21] and Tiwari et al. [22]; that is, the status was good regeneration, if seedlings > saplings > adults; the status was fair regeneration, if seedlings $>$ or $\leq$ saplings $\leq$ adults; the status was poor regeneration, if the species survives only in sapling stage (saplings may be $\leq$ or $\geq$ adults); and if a species is present only in an adult form it is considered as not regenerating. Multivariate data analysis was carried out using XLSTAT version 2015.2.01.

\section{Results}

3.1. Species Composition. A total of 62 woody species representing 54 genera and 32 families were identified. Out of the total families $58.8 \%$ were represented by one species. Fabaceae (8 species) and Combretaceae and Oleaceae (4 species each) were found to be the most species rich families but some of the families like Vitaceae, Ulmaceae, Thymelaeaceae, Ebenaceae, Olacaceae, and Myrsinaceae were found to be the least species rich families (1 species each). 


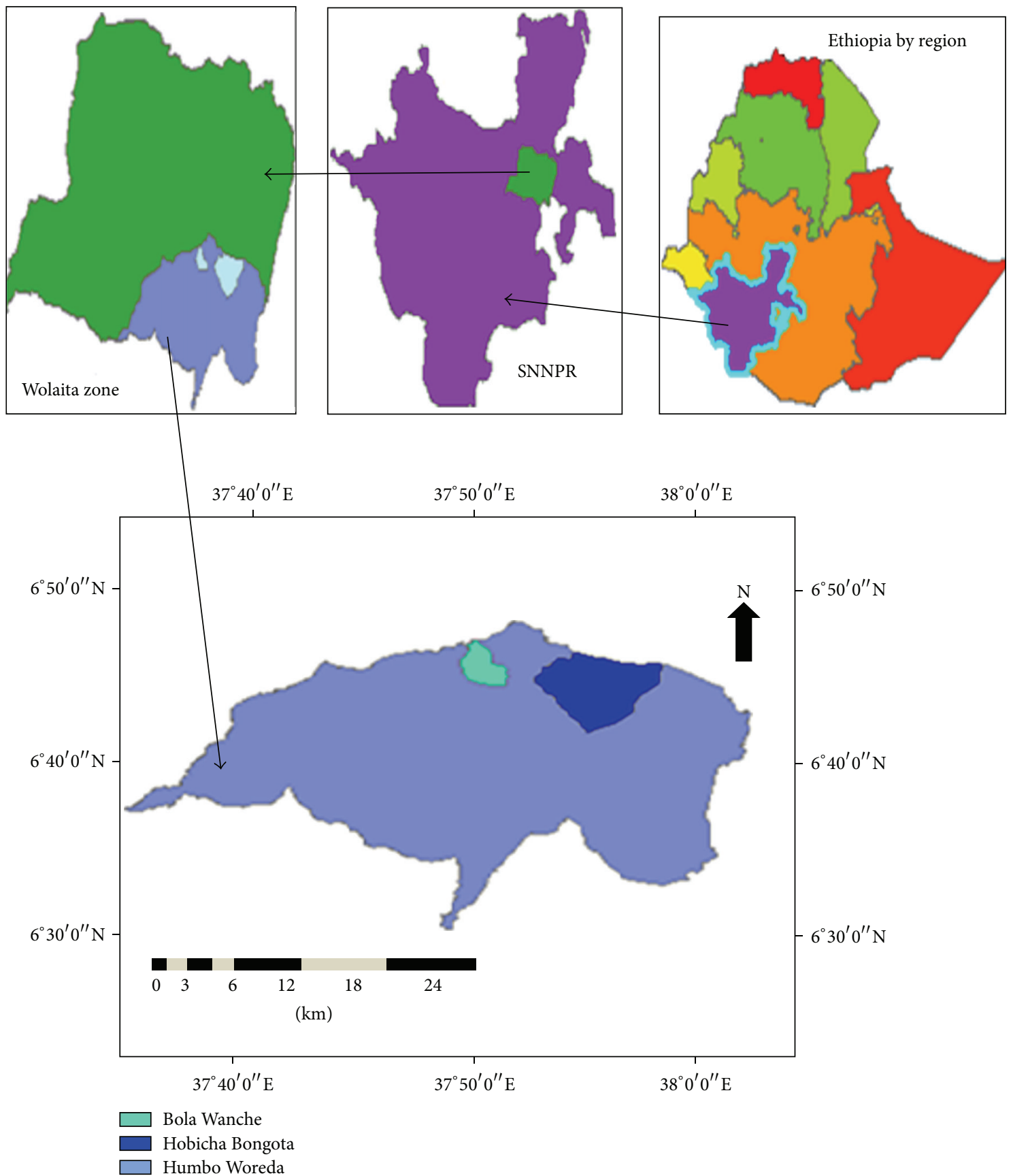

Figure 1: Map of study area.

Calpurnia aurea from Fabaceae, Schrebera alata from Oleaceae, and Combretum molle from Combretaceae were found to be the most abundant species. 38 species (62.5\%) in the forest were represented by importance value less than $1 \%$. Some of the species included in this group were Combretum aculeatum, Croton macrostachyus, Uvaria schweinfurthii, Maytenus gracilipes, Protea gaguedi, Capparis fascicularis, and Ozoroa pulcherrima. Dodonaea angustifolia and Combretum molle were found to be the most dominant and abundant species in the forest and constituted $27.3 \%$ of the total importance value. But $72.7 \%$ of importance value represented
60 species including the least abundant species like Sansevieria ehrenbergii, Rytigynia neglecta, Erica arborea, Ocimum gratissimum, Triumfetta brachyceras, and Grewia velutina.

3.2. Vegetation Structure. The total density of woody species in Oda forest was $4745 \pm 22.957 \mathrm{SE}$ individuals $\mathrm{ha}^{-1}$. Dodonaea angustifolia has the highest density ha ${ }^{-1}$ (1295) followed by Combretum molle (625). But Grewia velutina and Triumfetta brachyceras have the least density of individuals $\mathrm{ha}^{-1}$ (0.61). The density of Euclea schimperi, Rhus natalensis, Combretum collinum, and Schrebera alata was 291, 262, 203, 


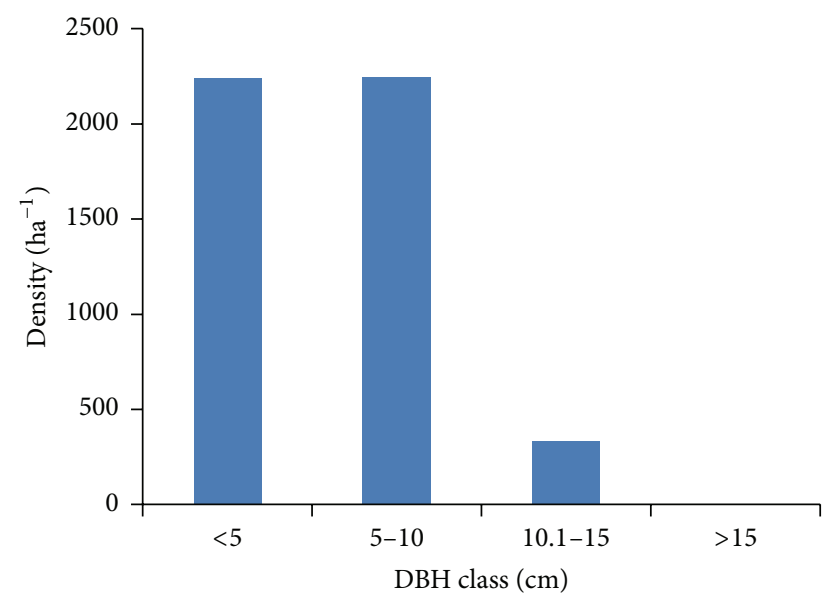

FIGURE 2: Vegetation structure of Oda forest.

and 202 individuals $\mathrm{ha}^{-1}$. On the other hand, Grewia velutina, Triumfetta brachyceras, Erica arborea, Ocimum gratissimum, Rytigynia neglecta, Sansevieria ehrenbergii, Ximenia americana, and Solanum incanum have the density less than five individuals $\mathrm{ha}^{-1}$. There is significant difference in density between species $(p<0.02)$. The most frequent woody species was Dodonaea angustifolia (i.e., 1) followed by Combretum molle (i.e., 0.94) but the least frequent species were Grewia velutina, Triumfetta brachyceras, Erica arborea, Ocimum gratissimum, Pterolobium stellatum, Rytigynia neglecta, Sansevieria ehrenbergii, and Pappea capensis (i.e., 0.03), Table 1. The multivariate tests indicated that frequency of species is significantly affected by slope $(p<0.002)$, altitude $(p<$ $0.0001)$, and aspect $(p<0.001)$ at adjusted $R^{2}=0.597$. The total mean dominance of woody species was $209651 \pm$ 906.219 SE. Combretum molle (21.9\%) is found to be the most dominant species followed by Acokanthera schimperi (10.7\%). But the species of less than $0.01 \%$ dominance were Osyris quadripartite, Clutia lanceolata, Sansevieria ehrenbergii, Capparis fascicularis, Ximenia americana, Triumfetta brachyceras, Grewia velutina, Gnidia glauca, Rytigynia neglecta, Crotalaria pallid, Erica arborea, Ocimum gratissimum, and Pterolobium stellatum. Dodonaea angustifolia (14.1\%) had the highest IVI followed by Combretum molle (13.2\%). Species with IVI less than 2\% included Solanum incanum, Ximenia americana, Sansevieria ehrenbergii, Rytigynia neglecta, Erica arborea, Ocimum gratissimum, Triumfetta brachyceras, and Grewia velutina, Table 1 . The altitude and slope have an equally strong significant $(p<0.0001)$ effect on basal area and dominance of species between quadrats.

3.3. Population Structure of the Forest and Selected Woody Species. The species density distribution by $\mathrm{DBH}$ class of Oda forest showed right skewed pattern (Figure 2). However, this pattern does not depict the general trends of population dynamics and recruitment processes of a given species. Analysis of population structures for each individual tree and shrub species could provide more realistic and specific information for conservation measures.
Diameter class distribution of selected tree species demonstrated various patterns of population structure, implying different population dynamics among species. In Combretum molle and Combretum collinum the DBH class $<5 \mathrm{~cm}$ has the least species distribution (i.e., $11.3 \%$ and $5.7 \%$, resp.) but the highest density (69.1\% and $66.8 \%$, resp.) is found in DBH class $5-10 \mathrm{~cm}$. In Acokanthera schimperi and Schrebera alata the DBH class $10.1-15 \mathrm{~cm}$ has the least species distribution (i.e., $7.4 \%$ and $6 \%$, resp.) but the highest species distribution (i.e., $71.3 \%$ and $74.3 \%$, resp.) was found in $\mathrm{DBH}$ class 5-10 cm. In Euclea schimperi, 44.9\% species distribution was in DBH class $<5 \mathrm{~cm}, 50 \%$ distribution was in $\mathrm{DBH}$ class $5-10 \mathrm{~cm}$, and $5.1 \%$ distribution was in DBH class $10.1-$ $15 \mathrm{~cm}$. Therefore, these species resulted in bell shaped pattern; however Combretum molle and Combretum collinum have higher species density distribution in DBH class $10.1-15 \mathrm{~cm}$ than that of Acokanthera schimperi and Schrebera alata. In bell shaped pattern the middle DBH classes have higher species density distribution than the lower and higher DBH classes. In Dodonaea angustifolia higher species density (78.7\%) distribution is found in DBH class $<5 \mathrm{~cm}$ but lower species distribution $(21.3 \%)$ is found in DBH class $5-10 \mathrm{~cm}$. Therefore it resulted in inverted $\mathrm{J}$ shaped pattern. In general, except in Combretum molle the DBH class $>15 \mathrm{~cm}$ has no species distribution in all other selected species, Figure 3.

3.4. Regeneration Status. In Oda forest 55 species (89.1\%), 9 species $(15.6 \%)$, and 5 species $(7.8 \%)$ have no seedling, sapling, and matured tree, respectively. On the other hand the seedling, sapling, and matured tree consist of $2.3 \%, 23.7 \%$, and $74 \%$ density $\mathrm{ha}^{-1}$ of individuals, respectively. The only woody species representing the seedling stage are Combretum molle, Dodonaea angustifolia, Euclea schimperi, Hypericum revolutum, Myrtus communis, and Olea capensis. Woody species that had no representation of seedling and sapling stage are Entada abyssinica, Ficus vasta, Grewia velutina, Myrtus communis, Rhoicissus revoilii, Rytigynia neglecta, Triumfetta brachyceras, and Ximenia americana but Capparis fascicularis, Crotalaria pallid, Ocimum gratissimum, and Solanum incanum had no representation of seedling and matured tree. Dodonaea angustifolia was the most abundant species in seedling (72\%), sapling (25.8\%), and matured stage (25.7\%). Grevillea robusta and Myrtus communis were species with only one individual in seedling but Celtis africana, Croton macrostachyus, Erica arborea, Grevillea robusta, and Pappea capensis were species with one individual in sapling stage. In matured stage Erica arborea, Grewia velutina, and Triumfetta brachyceras were species with one individual.

\section{Discussion}

In this study Fabaceae are the most dominant family with 8 species. The dominance of Fabaceae was reported from similar vegetation studies [23-28]. The dominance indicates suitability of the condition and adaptation of the environment for Fabaceae. Similar to Didita et al. [28] study, most families $(58.8 \%)$ of Oda forest were represented by one species. In the forest high dominance (i.e., 50.1\%) is occupied by a few species (Combretum molle, Acokanthera schimperi, Dodonaea 
TABLE 1: Density ha ${ }^{-1}$, dominance, frequency, and IVI of species.

\begin{tabular}{|c|c|c|c|c|}
\hline Scientific name & Density ha $^{-1}$ & Frequency & Dominance & IVI \\
\hline Acacia hockii De Wild. & 65 & 0.56 & 3733 & 5.9 \\
\hline Acacia senegal (L.) Willd. & 45 & 0.09 & 343 & 1.6 \\
\hline Acokanthera schimperi (A.DC.) Schweinf. & 48 & 0.19 & 22332 & 12.6 \\
\hline Albizia schimperiana Oliv. & 26 & 0.41 & 318 & 1.5 \\
\hline Allophylus abyssinicus (Hochst.) Radlk. & 49 & 0.72 & 945 & 5.0 \\
\hline Calpurnia aurea (Ait.) Benth. & 133 & 0.53 & 3797 & 7.2 \\
\hline Capparis fascicularis & 6 & 0.19 & 13 & 1.0 \\
\hline Carissa edulis(Forssk.) Vahl & 181 & 0.72 & 4894 & 9.6 \\
\hline Celtis africana Burm. $\mathrm{f}$. & 11 & 0.13 & 530 & 1.1 \\
\hline Clutia abyssinica Jaub. \& Spach & 36 & 0.52 & 665 & 3.6 \\
\hline Clutia lanceolata Forssk. & 14 & 0.41 & 15 & 2.0 \\
\hline Combretum aculeatum Vent. & 20 & 0.31 & 871 & 2.3 \\
\hline Combretum collinum Fresen. subsp. binderianum (Kotschy) Okafor & 203 & 0.53 & 16186 & 14.6 \\
\hline Combretum molle (R. Br. ex G. Don) & 625 & 0.94 & 45871 & 39.7 \\
\hline Crotalaria pallida L. & 3 & 0.16 & 3 & 0.9 \\
\hline Croton macrostachyus Hochst. ex Delile. & 17 & 0.25 & 1311 & 2.2 \\
\hline Dichrostachys cinerea (L.) Wight \& Arn. & 95 & 0.75 & 2034 & 6.7 \\
\hline Dodonaea angustifolia L. f. & 1295 & 1 & 21447 & 42.3 \\
\hline Entada abyssinica Steud. ex A. & 3 & 0.19 & 145 & 1.1 \\
\hline Erica arborea $\mathrm{L}$. & 1 & 0.03 & 2 & 0.2 \\
\hline Euclea schimperi (A.DC.) Dandy & 291 & 0.52 & 10566 & 13.7 \\
\hline Ficus ingens (Miq.) Miq. & 10 & 0.09 & 331 & 0.9 \\
\hline Ficus vasta Forssk. & 3 & 0.09 & 6595 & 3.7 \\
\hline Flacourtia indica (Burm. f.) Merr. & 1 & 0.13 & 233 & 0.8 \\
\hline Gnidia glauca (Fresen.) Gilg. & 6 & 0.25 & 9 & 1.4 \\
\hline Grewia bicolor A. Juss. & 36 & 0.47 & 862 & 3.5 \\
\hline Grewia velutina (Forssk.) Vahl & 0.61 & 0.03 & 9 & 0.2 \\
\hline Hypericum revolutum Vahl. & 119 & 0.69 & 601 & 6.2 \\
\hline Jasminum floribundum R. Br. ex Fresen & 23 & 0.75 & 36 & 4.2 \\
\hline Maerua angolensis DC. & 20 & 0.44 & 690 & 2.9 \\
\hline Markhamia lutea (Benth.) K.Schum. & 18 & 0.41 & 655 & 2.4 \\
\hline Maytenus gracilipes (Welw. ex Oliv.) Exell & 13 & 0.47 & 82 & 2.6 \\
\hline Maytenus senegalensis (Lam.) Exell & 9 & 0.22 & 218 & 1.4 \\
\hline Myrsine africana $\mathrm{L}$. & 20 & 0.25 & 420 & 1.8 \\
\hline Myrtus communis L. & 70 & 0.59 & 2643 & 5.6 \\
\hline Ocimum gratissimum $\mathrm{L}$. & 1 & 0.03 & 0 & 0.2 \\
\hline Olea capensis L. & 133 & 0.34 & 7656 & 8.2 \\
\hline Olea europaea L. subsp. cuspidata (Wall. ex G. Don) Cif. & 139 & 0.53 & 8360 & 9.5 \\
\hline Olinia rochetiana A. Juss. & 54 & 0.34 & 1307 & 3.5 \\
\hline Osyris quadripartita Decn. & 12 & 0.41 & 15 & 2.0 \\
\hline Ozoroa pulcherrima (Schweinf.) R. \& A. Fernandes & 23 & 0.22 & 1842 & 2.5 \\
\hline Pappea capensis Eckl. \& Zeyh. & 5 & 0.03 & 497 & 0.6 \\
\hline Protea gaguedi J. F. Gmel. & 16 & 0.13 & 616 & 1.2 \\
\hline Pterolobium stellatum (Forssk.) Brenan · & 1 & 0.03 & 0 & 2.4 \\
\hline Rhamnus prinoides L'Herit. & 13 & 0.22 & 698 & 1.7 \\
\hline Rhoicissus revoilii Planch. & 10 & 0.25 & 44 & 1.5 \\
\hline Rhus natalensis Bernh. ex C.Krauss & 262 & 0.69 & 9648 & 13.5 \\
\hline Rothmannia urcelliformis (Hiern) Robyns & 15 & 0.09 & 213 & 0.9 \\
\hline Rytigynia neglecta (Hiern) Robyns & 1 & 0.03 & 5 & 0.2 \\
\hline
\end{tabular}


TABle 1: Continued.

\begin{tabular}{|c|c|c|c|c|}
\hline Scientific name & Density ha $^{-1}$ & Frequency & Dominance & IVI \\
\hline Salacia congolensis De Wild. \& Th. Dur. & 6 & 0.06 & 117 & 0.5 \\
\hline Sansevieria ehrenbergii Schweinf. ex Baker & 1 & 0.03 & 14 & 0.2 \\
\hline Schrebera alata (Hochst.) Welw. & 202 & 0.69 & 10233 & 12.5 \\
\hline Solanum incanum L. & 1 & 0.06 & 2 & 0.3 \\
\hline Steganotaenia araliacea Hochst. ex A. Rich. & 2 & 0.09 & 295 & 0.7 \\
\hline Syzygium guineense (Willd.) DC. & 143 & 0.47 & 8611 & 9.4 \\
\hline Teclea nobilis Del. & 9 & 0.16 & 505 & 1.2 \\
\hline Terminalia schimperiana Hochst. & 99 & 0.72 & 6146 & 8.5 \\
\hline Tricalysia niamniamensis Hiern & 33 & 0.09 & 824 & 1.6 \\
\hline Triumfetta brachyceras K.Schum. & 0.61 & 0.03 & 11 & 0.2 \\
\hline Uvaria scheffleri Diels. & 34 & 0.22 & 621 & 2.1 \\
\hline Vernonia karaguensis Oliv. & 19 & 0.25 & 706 & 2.0 \\
\hline Ximenia americana L. & 1 & 0.06 & 12 & 0.3 \\
\hline
\end{tabular}

angustifolia, and Combretum collinum). Dodonaea angustifolia had the highest IVI (14.1\%) followed by Combretum molle (13.2\%). According to Feyera [29] the high dominance and/or abundance of a few species in a forest could be attributed to a number of factors, such as the overharvesting of the desired species, disturbance factors, successional stage of the forest, and/or survival strategies of the species. Many ecological studies [30-33] on A. abyssinica, C. aurea, D. angustifolia, Myrsine africana, and Polyscias fulva revealed that they are successional species. Therefore, Dodonaea angustifolia has been the third dominant species affirming that the Oda forest was in early successional stage. Deribe [12] indicated from his field observation that 26 species would be at maturity of the forests of Humbo Carbon Project. However, our study confirmed the presence of 62 woody species in Oda forest including the planted species like Grevillea robusta.

The population structure in Oda forest established two groups of woody plant species from six species selected by their dominance. The first group includes Combretum molle, Combretum collinum, Acokanthera schimperi, Euclea schimperi, and Schrebera alata which showed bell shaped pattern. In bell shaped pattern the distribution of individuals of a species in the middle diameter classes is high and low in lower and higher diameter classes. According to Feyera et al. [34] bell shaped pattern indicates a poor reproduction and recruitment of species which may be associated with intense competition from the surrounding trees. The second group includes Dodonaea angustifolia which resulted in inverted J shaped pattern. Inverted J shaped pattern shows high distribution of individuals of a species in the lower diameter classes and a gradual decrease towards the higher classes. In other words, it shows good reproduction and recruitment potential of the species. Population structure of the forest and selected woody species indicated the absence of individuals in almost all species of the forest in DBH class $>15 \mathrm{~cm}$. This and field observation during data collection clearly confirmed the occurrence of high disturbance in matured tree of the forest by cutting of trees for charcoal production, firewood, house construction, and fencing.

In Oda forest most of the woody species (89.1\%) had no seedling. The only woody species representing the seedling stage are Combretum molle, Dodonaea angustifolia, Euclea schimperi, Hypericum revolutum, Myrtus communis, and Olea capensis. In the forest the seedling, sapling, and matured tree accounted for $2.3 \%, 23.7 \%$, and $74 \%$ density $\mathrm{ha}^{-1}$ of individuals, respectively. Density ha ${ }^{-1}$ of individuals of species showed that the seedling < sapling < matured tree in Oda forest. According to Dhaulkhandi et al. [21], the density values of seedling and saplings are considered as regeneration potential of the species. Based on the criteria of Dhaulkhandi et al. [21] and Tiwari et al. [22] the forest of Oda was categorized under the forests with fair regeneration. In the present study area, some physiographic conditions, worse habitats, lack of awareness of villagers for conservation of forest, series previous disturbance occurring in the area, and immaturity of old trees to produce seed were considered as the causes of less regeneration of the forest. Dodonaea angustifolia was the most abundant species in seedling (72\%) and sapling (25.8\%). Grevillea robusta and Myrtus communis were species with only one individual in seedling and Celtis africana, Croton macrostachyus, Erica arborea, Grevillea robusta, and Pappea capensis were species with one individual in sapling stage.

Altitude and slope of Oda forest significantly affected the basal area, dominance, and frequency of species while the aspect of vegetation significantly affected only the distribution of the species. The effect of altitude, aspect, and slope on dominance, basal area, and distribution of species is mainly related with their influence on light radiation, temperature, moisture, runoff, and infiltration. Similarly, Kumelachew and Tamrat [35], Hedberg [36] confirmed the effect of altitude on radiation, temperature, atmospheric pressure, and moisture. Besides, Teshome et al. [24] ensured effect of slope on runoff, drainage, and moisture. The influence of slope, altitude, and aspect of vegetation on moisture availability not only affects 

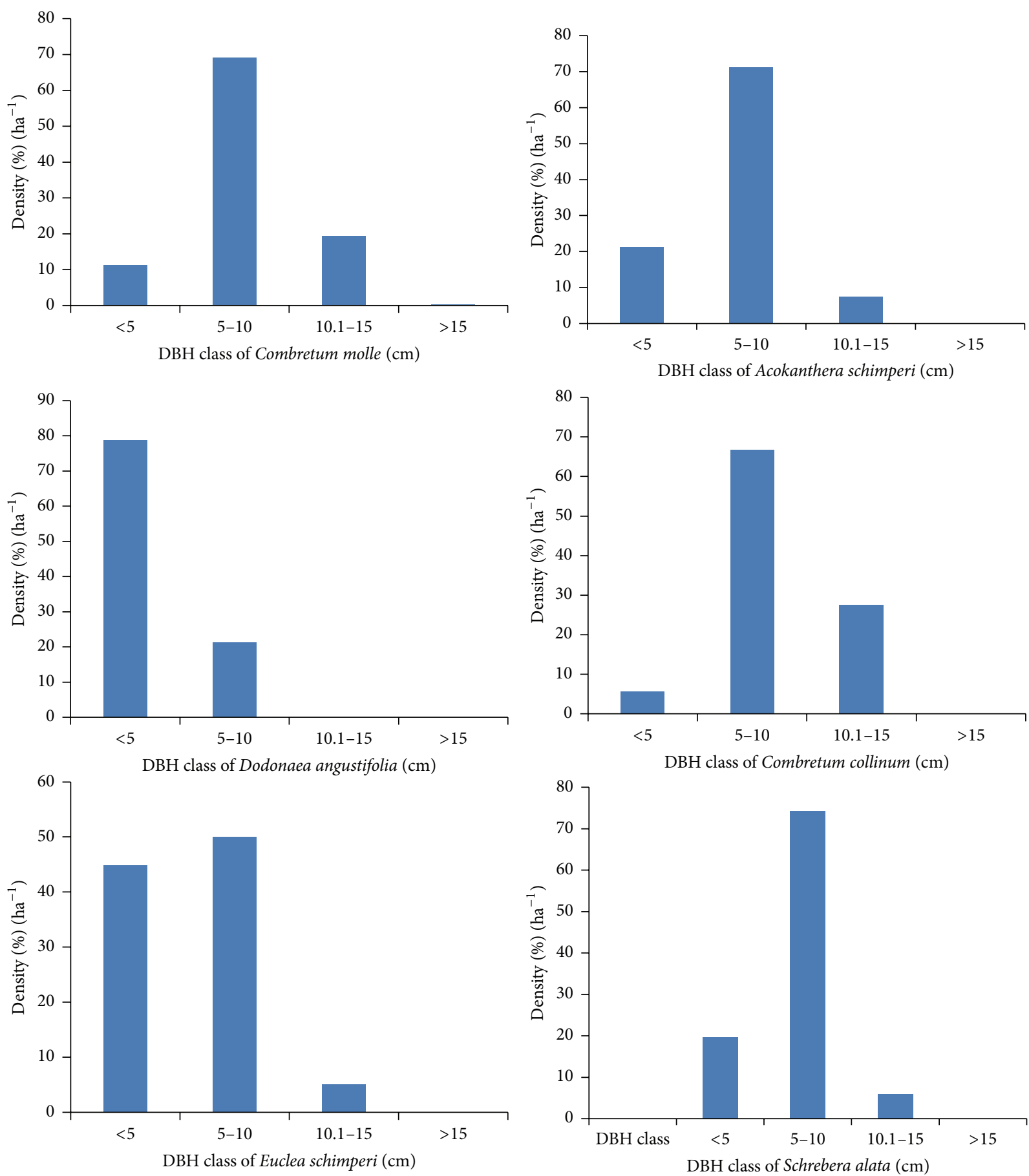

FIGURE 3: Vegetation structure of selected dominant species.

the dominance, basal area, and distribution of species but also affects regeneration status of the vegetation. It is also similar to $\mathrm{McD}$ onald et al. [37] idea, which states that the sensitivity of plants to moisture availability renders the regeneration of the dry forests. The regeneration of the forest is affected not only by environmental factors but also by anthropogenic activities. Some of the anthropogenic activities seriously observed during data collection were cutting of trees for charcoal production, constructing wood, fence, and mowing grasses for fodder and covering roof of house which are related with observation by Deribe [12].

\section{Conclusion and Recommendation}

Humbo Community-Based Forest Management Project is a reforestation forestry project designed for sequestration of carbon through biodiverse native of natural forest managed by the local community. Oda forest is one of the seven forests 
demarcated in seven kebele associations. It consists of 62 woody species representing 54 genera and 32 families. Among these species Dodonaea angustifolia and Combretum molle were found to be the densest and the most dominant and frequent species with higher IVI in the forest. Frequency of species is significantly affected by slope $(p<0.002)$, altitude $(p<0.0001)$, and aspect $(p<0.001)$. Besides, altitude and slope have an equally strong significant $(p<0.0001)$ effect on basal area and dominance of species between quadrats. The population structure of selected woody species established two groups (bell shaped and inverted J shaped patterns). In Oda forest 55 species (89.1\%), 9 species (15.6\%), and 5 species (7.8\%) have no seedling, sapling, and matured tree, respectively. On the other hand, the seedling, sapling, and matured tree consist of $2.3 \%, 23.7 \%$, and $74 \%$ density ha ${ }^{-1}$ of individuals, respectively. The forest of Oda was categorized under the forests with fair regeneration because the density $\mathrm{ha}^{-1}$ of seedling is less than that of sapling. Therefore the government, NGOs, and community must give conservation and management priority for species with IVI less than $1 \%$, species with no seedling, and families represented by only one species.

\section{Conflict of Interests}

Markos Kuma and Simon Shibru, the authors of the paper, declare that there is no conflict of interests regarding its publication.

\section{Acknowledgments}

The authors thank Humbo Woreda administrator and World Vision Ethiopia, Humbo branch, for their permission to conduct this research in Humbo Carbon Project site. They are grateful to Wolaita Sodo University for financial support and Arba Minch University for giving the chance to carry out the research.

\section{References}

[1] G. K. Sahle, An ecological study of the vegetation on the eastern escarpment of Eritrea, Ethiopia [M.S. thesis], School of Graduate Studies, Addis Ababa University, Addis Ababa, Ethiopia, 1984.

[2] K. Curry-Lindahl, Conservation for Survival: Ethiopia's Choice, HIS University Press, Addis Ababa, Ethiopia, 1972.

[3] W. Gebremarkos, "The forest resources of Ethiopia: past and present," Journal of the Ethiopian Wildlife and Natural History Society: Walia, vol. 19, pp. 10-28, 1998.

[4] D. Teketay, "Deforestation, wood famine, and environmental degradation in Ethiopia's highland ecosystems: urgent need for action," Northeast African Studies, vol. 8, no. 1, pp. 53-76, 2001.

[5] FAO, "Role of planted forests and trees outside forests in sustainable forest management in the republic of Ethiopia," Working Paper 29, FAO, Rome, Italy, 2003.

[6] T. Tsegaye, "An overview of the forest ecosystems of Ethiopia: functions, trends and future directions," in Environment for Survival Taking Stock of Ethiopia's Environment: Proceedings of the First Green Forum Conference Held in Addis Ababa, Ethiopia, M. Seyoum and C. Stoop, Eds., pp. 18-34, Green Forum, 2006.
[7] R. Jandl, K. Rasmussen, M. Tomé, and D. W. Johnson, The Role of Forests in Carbon Cycles, Sequestration and Storage. Issue 4. Forest Management and Carbon Sequestration, Federal Research and Training Centre for Forests, Natural Hazard and Landscape (BFW), Vienna, Austria, 2006.

[8] E. Sundquist, B. Robert, F. Stephen et al., Carbon Sequestration to Mitigate Climate Change, US Geological Survey, Science for a Changing World, New York, NY, USA, 2008.

[9] M. Yetebitu, E. Zewdu, and N. Sisay, "Manual for assessment and monitoring of carbon in forest and other land uses in Ethiopia," Tech. Rep., Ethiopian Forest Research Center, Addis Ababa, Ethiopia, 2010.

[10] R. Valencia, R. Condit, H. C. Muller-Landau, C. Hernandez, and H. Navarrete, "Dissecting biomass dynamics in a large amazonian forest plot," Journal of Tropical Ecology, vol. 25, no. 5, pp. 473-482, 2009.

[11] R. W. McEwan, Y.-C. Lin, I.-F. Sun et al., "Topographic and biotic regulation of aboveground carbon storage in subtropical broad-leaved forests of Taiwan," Forest Ecology and Management, vol. 262, no. 9, pp. 1817-1825, 2011.

[12] G. Deribe, "Humbo community-managed natural regeneration project final report," Report, Humbo Regeneration Project, Addis Ababa, Ethiopia, 2006.

[13] M. Asfaw, "World vision Ethiopia," Humbo/Soddo Community Based Forest Management Project Activity Accomplishment Report, 2006.

[14] Donaldson, "Humbo community managed forestry project," Climate Change Case Studies, World Vision, Addis Ababa, Ethiopia, 2009.

[15] FAO, State of the World's Forests, FAO, Forestry Department, 2007.

[16] I. Hedberg and S. Edwards, Eds., Flora of Ethiopia and Eritrea, Vol. 3: Pittosporaceae to Araliaceae, National Herbarium, Addis Ababa University, Addis Ababa, Ethiopia; Department of Systematic Botany, Uppsala University, Uppsala, Sweden, 1989.

[17] S. Edwards, T. Mesfin, and I. Hedberg, Eds., Flora of Ethiopia and Eritrea, Vol.2 Part 2: Canellaceae to Euphorbiaceae, The National Herbarium, Addis Ababa, Ethiopia, 1995.

[18] I. Hedberg and S. Edwards, Eds., Flora of Ethiopia and Eritrea, Volume 7: Poaceae (Gramineae), Addis Ababa University, Addis Ababa, Ethiopia; Uppsala University, Uppsala, Sweden, 1997.

[19] S. Edwards, D. Sebsebe, and I. Hedberg, Eds., Flora of Ethiopia and Eritrea, Volume 6: Hydrocharitaceae to Ericacea, Addis Ababa University, Addis Ababa, Ethiopia; Uppsala University, Uppsala, Sweden, 1997.

[20] I. Hedberg, S. Edwards, and N. Sileshi, Eds., Flora of Ethiopia and Eritrea. Vol. 4, Part 1: Apiaceae to Dipsacaceae, National Herbarium, Addis Ababa University, Addis Ababa, Ethiopia; Department of Systematic Botany, Uppsala University, Uppsala, Sweden, 2003.

[21] M. Dhaulkhandi, A. Dobhal, S. Bhatt, and M. Kumar, "Community structure and regeneration potential of natural forest site in Gangotri, India," Journal of Basic \& Applied Sciences, vol. 4, pp. 49-52, 2008.

[22] G. P. K. Tiwari, K. Tadele, F. Aramde, and S. C. Tiwari, "Community structure and regeneration potential of shorearobusta forest in subtropical submontane zone of Garhwal Himalaya, India," Nature and Science, vol. 8, pp. 70-74, 2010.

[23] D. Gemedo, Vegetation ecology, rangeland condition and forage resources evaluation in the Borana Lowlands, Southern Oromia, Ethiopia [Doctoral dissertation], Georg-August University, Göttingen, Germany, 2004. 
[24] S. Teshome, T. Demel, and D. Sebsebe, "Ecological study of the vegetation in Gamo Gofa zone, Southern Ethiopia," Journal of Tropical Ecology, vol. 45, no. 2, pp. 209-221, 2004.

[25] B. Anteneh, Floristic description and ethno botanical study of the natural vegetation in the Babile Elephant Sanctuary, Ethiopia [M.S. thesis], AAU, Addis Ababa, Ethiopia, 2006.

[26] T. Negusse, Ecology and plant use diversity in Sof Umer area of Bale, Southeastern Ethiopia [M.S. thesis], AAU, Addis Ababa, Ethiopia, 2006.

[27] G. Tadesse, T. Bekele, and S. Demissew, "Dryland woody vegetation along an altitudinal gradient on the eastern escarpment of Welo, Ethiopia," Ethiopian Journal of Science, vol. 31, no. 1, pp. 43-54, 2008.

[28] M. Didita, S. Nemomissa, and T. W. Gole, "Floristic and structural analysis of the woodland vegetation around Dello Menna, Southeast Ethiopia," Journal of Forestry Research, vol. 21, no. 4, pp. 395-408, 2010.

[29] S. Feyera, Biodiversity and Ecology of Afromontane Rainforests with Wild Coffea arabica L. Populations in Ethiopia, Ecology and Development Series no. 38, Cuvillier, Göttingen, Germany, 2006.

[30] R. Fichtl and A. Admasu, Honeybee Flora of Ethiopia, Margraf Verlag, Weikersheim, Germany, 1994.

[31] I. Friis, "Moraceae," in Flora of Ethiopia, I. Hedberg and S. Edwards, Eds., vol. 3, pp. 271-301, The National Herbarium, Addis Ababa University, Addis Ababa, Ethiopia; Department of Systematic Botany, Uppsala University, Uppsala, Sweden, 1989.

[32] M. Thulin, "Fabaceae," in Flora of Ethiopia, I. Hedberg and S. Edwards, Eds., vol. 3, pp. 49-251, The National Herbarium, Addis Ababa University, Addis Ababa, Ethiopia; Department of Systematic Botany, Uppsala University, Uppsala, Sweden, 1989.

[33] K. Vollesen, "Sapindaceae," in Flora of Ethiopia, I. Hedberg and S. Edwards, Eds., vol. 3, pp. 490-510, National Herbarium, Addis Ababa University, Addis Ababa, Ethiopia; Department of Systematic Botany, Uppsala University, Uppsala, Sweden, 1989.

[34] S. Feyera, W. Tadesse, D. Sebsebe, and M. Denich, "Floristic diversity and composition of Sheko forest, Southwest Ethiopia," Ethiopian Journal of Biological Sciences, vol. 6, pp. 11-42, 2007.

[35] Y. Kumelachew and B. Tamrat, "Plant community analysis and ecology of afromontane and transitional rainforest vegetation of Southwestern Ethiopia," SINET: Ethiopian Journal of Science, vol. 25, no. 2, pp. 155-175, 2002.

[36] O. Hedberg, "Features of the Afroalpine plantecology," Acta Phytogeographica Suecica, vol. 49, pp. 1-144, 1964.

[37] M. A. McDonald, K. P. McLaren, and A. C. Newton, "What are the mechanisms of regeneration post-disturbance in tropical dry forest? CEE review 07-013 (SR37)," Environmental Evidence, 2010, http://www.environmentalevidence.org/SR37.html. 

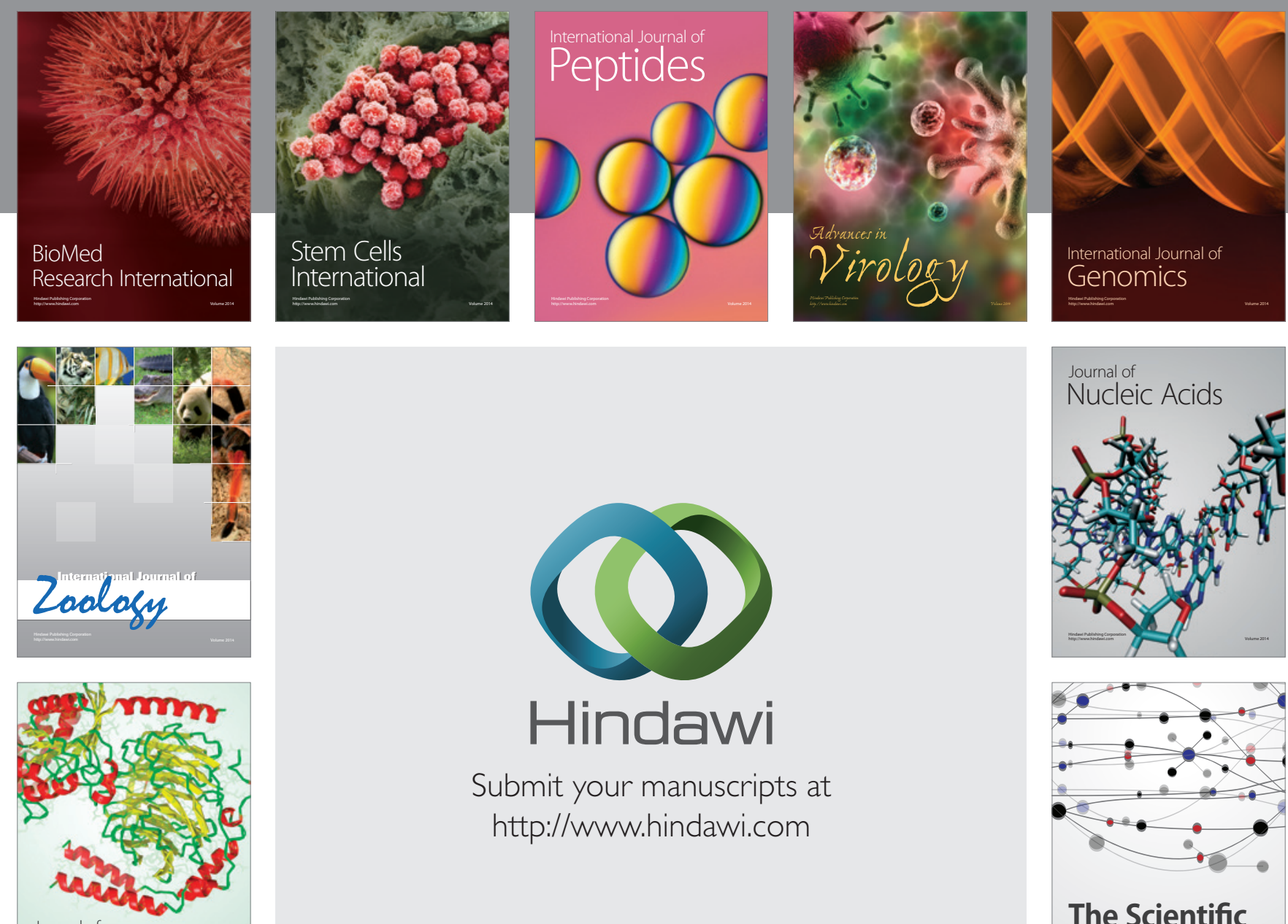

Submit your manuscripts at

http://www.hindawi.com

Journal of
Signal Transduction
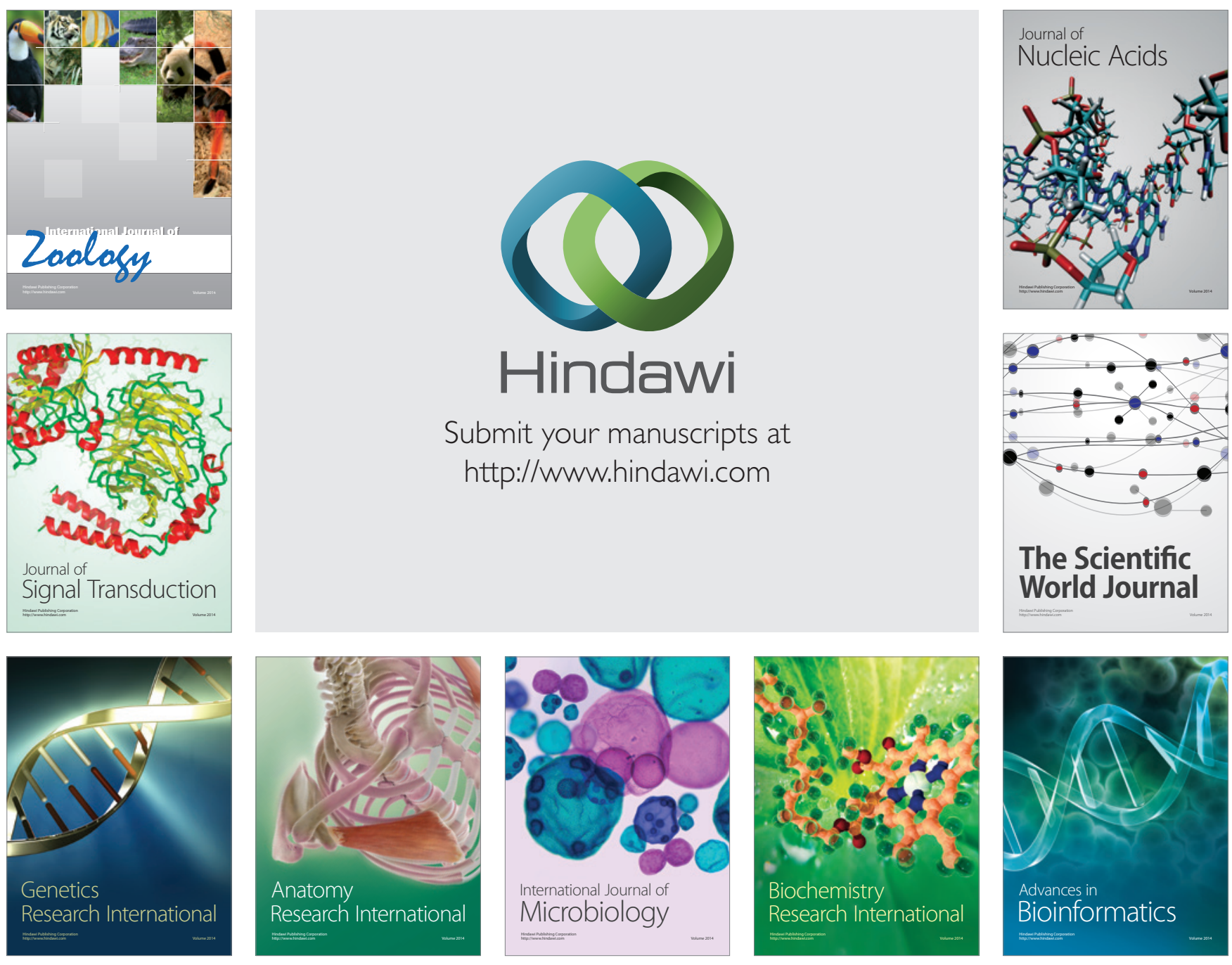

The Scientific World Journal
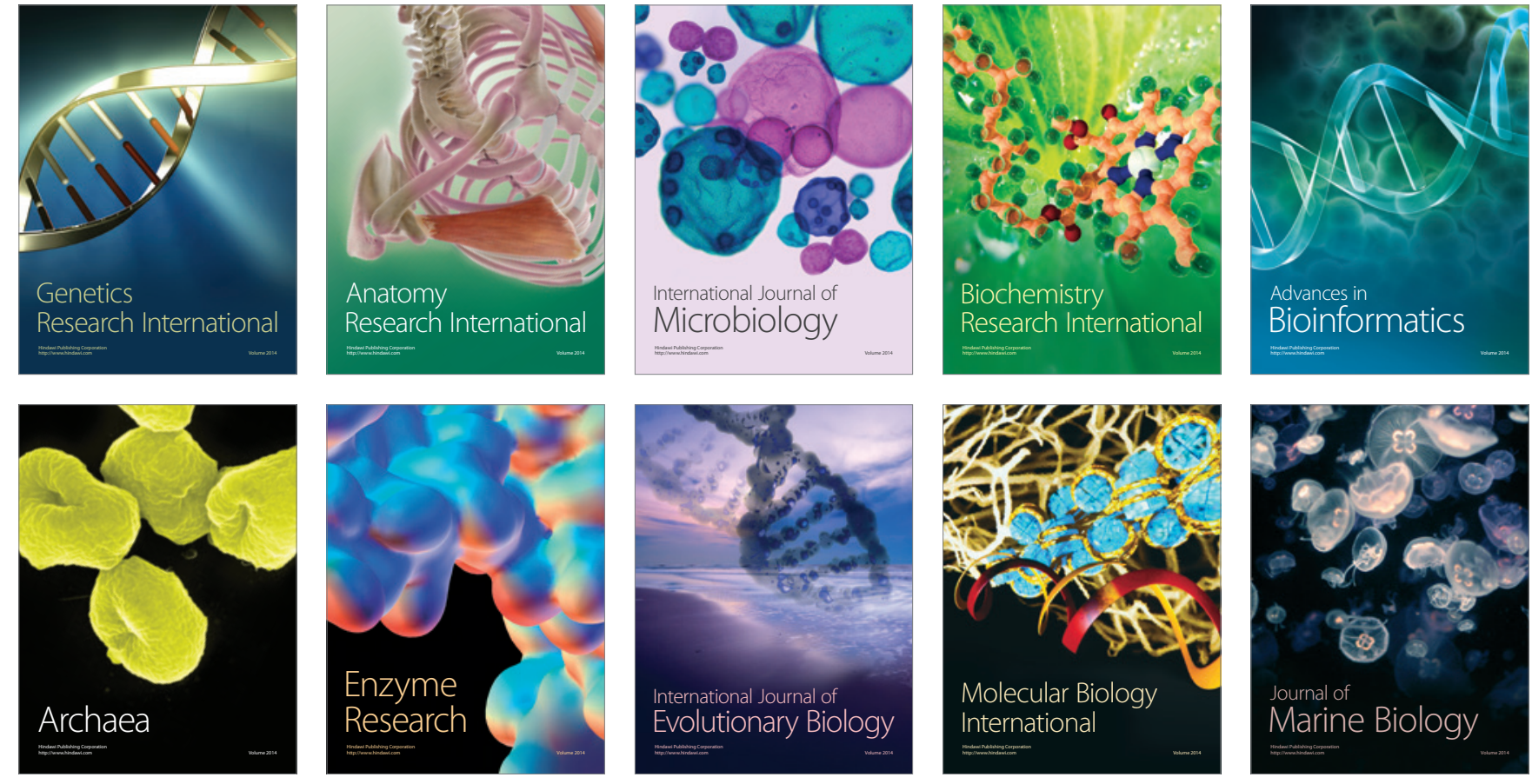